\title{
POLLEN COLLECTION AND HONEY BEE FORAGER DISTRIBUTION IN CANTALOUPE
}

\author{
José Luis Reyes-Carrillo', Frank A. Eischen², Pedro Cano-Rıos ${ }^{3}$, Rafael Rodriguez- \\ MARTINeZ $Z^{1}$ and Urbano Nava CAmberos ${ }^{3}$ \\ ${ }^{1}$ Universidad Autónoma Agraria Antonio Narro, U.L. \\ Carr. a Santa Fe y periférico, Torreón, Coahuila, CP 27000 MÉXICO \\ jlreyes54@yahoo.com.mx \\ ${ }^{2}$ Honey Bee Unit, USDA-ARS-SARC, 2413 E. Hwy 83 Weslaco, Texas 78596 USA \\ feischen@weslaco.ars.usda.gov \\ 3INIFAP-Celala, Matamoros, Coahuila, MÉXICO \\ autor de correspondencia cano.pedro@inifap.gob.mx
}

\section{RESUMEN}

Durante el verano del 2002 la colecta de polen y la distribución de las abejas (Apis mellifera L.) pecoreadoras fueron estudiadas en el cultivo de melón (Cucumis melo L., cv Cruiser ) bajo condiciones de riego por goteo y acolchado plástico. El lote experimental estuvo localizado cerca del Campo Experimental La Laguna del INIFAP, en el municipio de Matamoros, Coahuila, México. Dos experimentos se realizaron en el mismo predio, en lotes separados $800 \mathrm{~m}$ por una huerta de nogal. Ambas superficies de melón fueron sembradas en la misma fecha. Experimento $\mathrm{N}^{\circ} 1$. Al inicio de la floración se colocaron nueve colmenas en tres hectáreas de cultivo. Cada colmena contó con una trampa de polen tipo Ontario modificada. El polen se colectó cada hora de cada colmena un día por semana de las $8: 30 \mathrm{hr}$ a las $14: 30 \mathrm{hr}$ durante las cuatro primeras semanas de floración del cultivo. Experimento $\mathrm{N}^{\circ} 2$. Tres semanas después del inicio de la floración se colocaron 30 colmenas en un campo de melón de diez hectáreas. En cuatro surcos de $105 \mathrm{~m}$ de longitud se marcaron transectos de diez metros a 25, 50, 75 y 100 metros de distancia del apiario. Las abejas pecoreadoras fueron contadas simultáneamente en cada transecto cada media hora de las 7:30 hr hasta las 20:30 horas, el mismo día en que fue colectado el polen de la tercera semana de floración. La colecta de polen fue mayor temprano por la mañana (22.6 g por colmena), disminuyendo a una cantidad media de las 9:30 hr (13.7 g), 10:30 hr (12.5 g) a las $11: 30 \mathrm{hr}(9.5 \mathrm{~g})$ y permaneciendo baja desde las $12: 30$ hasta el mediodía (menos de $2.6 \mathrm{~g}$ por colmena; $\mathrm{p}<$ 0.05). El patrón de distribución mostró que las abejas se presentaron en el cultivo de melón después de las 8:00 hr y alcanzaron su máximo entre las 10:30 hr y las 14:30 hr cuando las abejas iniciaron su disminución hasta el cese de los vuelos a las 20:30 hr. No se encontraron diferencias significativas en el número de abejas pecoreadoras a las diferentes distancias del apiario que fueron evaluadas.

Palabras Clave: Apis mellifera, Cucumis melo, pecoreo, dispersión-abejas, polinización

\section{ABSTRACT}

Honey bee (Apis mellifera, L.) pollen collection and forager distribution were examined during the 2002 summer in a cantaloupe (Cucumis melo, L., Cruiser cv ) field with plastic mulch and drip

Mention of trade names or commercial products in this article only intends to provide specific information and does not imply recommendation or endorsement by the Universidad Autónoma Agraria Antonio Narro, U.L or the U.S. Department of Agriculture. 
Reyes-Carrillo et al.: Polen collection and bee forager in cataloupe

irrigated. The experimental site was located near the INIFAP Campo Experimental La Laguna, Matamoros, Coahuila within La Laguna region, Mexico. Two trials were conducted in the same location, but were separated by a $800 \mathrm{~m}$ wide pecan orchard. Both cantaloupe trials were planted the same date. Trial 1 . Nine honey-bee hives were placed in a three hectare field at the start of bloom. Each hive was fitted with a modified-Ontario pollen trap. The pollen was collected one day a week from each colony every hour beginning from 8:30 hr to $14: 30 \mathrm{hr}$ during the first four blooming weeks of the crop. Trial 2 . Three weeks after the start of bloom, in a ten-ha field 30 honey bee colonies were located. In four randomlyselected rows of $105 \mathrm{~m}$ long, $10 \mathrm{~m}$ transects at 25, 50, 75 and $100 \mathrm{~m}$ distances from the apiary were marked. The foraging bees were counted simultaneously at the transects every half hour from 7:30 hr until 20:30 hr at the same pollen collection-day during the third week of cantaloupe bloom. Pollen collection was higher early in the morning (22.6 g per colony), dropping to medium amount from 9:30 $\mathrm{hr}$ $(13.7 \mathrm{~g}), 10: 30 \mathrm{hr}(12.5 \mathrm{~g})$ to $11: 30 \mathrm{hr}(9.5 \mathrm{~g})$ and remaining low from 12:30 through the afternoon (less than $2.6 \mathrm{~g}$ per colony; $p<0.05$ ). The distribution pattern showed that bees were in the cantaloupe after 8:00 hr, reaching a maximum between $10: 30 \mathrm{hr}$ and $14: 30 \mathrm{hr}$ when the bees began to decrease, until foraging flights ceased completely at about 20:30 hr. No statistical differences were found in the number of foraging bees among the evaluated distances from the apiary.

Key Words: Apis mellifera, Cucumis melo, bee foraging, bee-dispersion, pollination

\section{INTRODUCTION}

For many field crops, yield and fruit quality would be greatly reduced without honey bee pollination. In vegetables, poor fruit quality is usually attributed to problems with pollination, e.g. low pollinator numbers or ineffective pollinators (Ricketts et al. 2004; Sheffield et al. 2005).

Selection on the amount of stored pollen in honey bee colonies changes the probability that worker bees will forage for pollen (Amdam et al. 2004). Foraging pollinators choose flowers according to the reward and energy foraging waste (Eckert 1933; Levin 1959; Lee 1961; Rush et al. 1995; Waser et al. 1996; Russell et al. 1998) and recently, flower symmetry (Waser et al. 1996; Endress 2001), floral scents, nectar production and color have been found to be factors in attractiveness (Briscoe \& Chittka 2001; Varassini et al. 2001).

Cantaloupe pollen is transferred by insects (McGregor 1976), for this reason this crop requires pollination by bees. Foraging activity of honey bees can be determined in different ways (Hagler \& Jackson 2001). In some arid and semi-arid areas wild pollinators are too scarce to assure an adequate pollination (Kearns, et al. 1998) as in northern Mexico and is necessary to induce the pollination with honey bees as a requirement for cantaloupe production.

We conducted this study to determine how much cantaloupe pollen is collected by honey bees and how they are temporally and spatially distributed throughout the first blooming month.

\section{MATERIALS AND METHOD}

This research was carried out during July and August of 2002, near the INIFAP Campo Experimental La Laguna, Matamoros, Coahuila. This region receives, on average $235 \mathrm{~mm}$ of rainfall, has an altitude of $1139 \mathrm{~m}$ above sea level and an annual mean temperature of $18.6^{\circ} \mathrm{C}$ (Schmidt 1989). Cantaloupe (Cruiser cultivar) rows were plastic 
mulched and drip irrigated. The 13 ha cantaloupe field was pollinated using three Italian honey bees (Apis mellifera ligustica, L.) colonies per hectare (McGregor 1976). Jumbosized colonies, headed by a young queen (Miel de La Laguna ${ }^{\circledR}$ queen breeder), were equalized to ca 24,000 workers. Colonies were located $10 \mathrm{~m}$ from the crop and equidistantly distributed adjacent to one side of the field. Two trials were done in the same location using fields that were separated (by a pecan orchard) by $800 \mathrm{~m}$. Both fields were planted the same date.

Trial $\mathbf{N}^{\circ} 1$. In a three-hectare cantaloupe field were placed nine pollinator bee-hives in order to determine the pattern of pollen collection in the first blooming month, which is considered optimal for pollination and fruit-set (Eischen et al. 1994). Each bee-hive had a modified-Ontario pollen trap (Waller 1980). In a particular day, from each week during the blooming period, pollen was collected from each colony every hour from 8:30 to 14:30 hours. Pollen was weighed fresh. Relative humidity, air field temperatures and rainfall were recorded using a portable digital weather station (Radio Shack®).

Trial $\mathbf{N}^{\circ} \mathbf{2}$. Honey-bee spatial and temporal distribution patterns were evaluated in a ten-ha cantaloupe field utilizing 30 pollinator bee-colonies. In four randomly-selected rows $105 \mathrm{~m}$ long, $10 \mathrm{~m}$ transects were marked (McGregor 1976) at 25, 50,75 and $100 \mathrm{~m}$ distances from the apiary. The foraging bees were counted simultaneously in the transects at the selected rows every 30 minutes from 8:00 hr to 20:30 hr the same day when pollen was collected during the third week of bloom. Data were examined with analysis of variance and whenever significant differences were found among means, they were separated using the Least Significance Difference (Steel \& Torrie 1960).

\section{RESULTS}

Pollen collection pattern: We found that corbicular pollen collection varied significantly $(f=22.62, d f=224 p=0.0001)$ across weeks of cantaloupe bloom (Table 1 ).

Table 1

Mean pollen collection $(g)$ by honey-bee colonies $(n=9)$ in the cantaloupe crop during the first blooming month.

\begin{tabular}{ccccccccc}
\hline week/time & $\mathbf{0 8 : 3 0}$ & $\mathbf{0 9 : 3 0}$ & $\mathbf{1 0 : 3 0}$ & $\mathbf{1 1 : 3 0}$ & $\mathbf{1 2 : 3 0}$ & $\mathbf{1 3 : 3 0}$ & $\mathbf{1 4 : 3 0}$ & $\begin{array}{c}\text { week } \\
\text { mean }\end{array}$ \\
\hline 1 & $8.4 \pm 2.16 \mathrm{~b}$ & $5.9 \pm 1.82 \mathrm{~b}$ & $8.3 \pm 2.53 \mathrm{~b}$ & $5.3 \pm 1.62 \mathrm{c}$ & $0.9 \pm 0.28 \mathrm{a}$ & $0.4 \pm 0.13 \mathrm{a}$ & $0.4 \pm 0.13 \mathrm{a}$ & $\mathbf{4 . 2 6 b}$ \\
2 & $27.9 \pm 7.26 \mathrm{a}$ & $19.1 \pm 4.95 \mathrm{a}$ & $22.8 \pm 5.92 \mathrm{a}$ & $19.8 \pm 5.12 \mathrm{a}$ & $2.8 \pm 0.73 \mathrm{a}$ & $0.8 \pm 0.20 \mathrm{a}$ & $0.7 \pm 0.18 \mathrm{a}$ & $\mathbf{1 3 . 4 2 a}$ \\
3 & $29.9 \pm 6.4 \mathrm{a}$ & $23.5 \pm 5.57 \mathrm{a}$ & $16.2 \pm 3.84 \mathrm{a}$ & $11.0 \pm 2.61 \mathrm{~b}$ & $5.3 \pm 1.25 \mathrm{a}$ & $1.8 \pm 0.43 \mathrm{a}$ & $1.2 \pm 0.27 \mathrm{a}$ & $\mathbf{1 2 . 2 7 a}$ \\
4 & $27.0 \pm 6.92 \mathrm{a}$ & $6.5 \pm 1.67 \mathrm{~b}$ & $2.9 \pm 0.75 \mathrm{c}$ & $2.1 \pm 0.54 \mathrm{c}$ & $1.5 \pm 0.37 \mathrm{a}$ & $1.2 \pm 0.36 \mathrm{a}$ & $0.9 \pm 0.23 \mathrm{a}$ & $\mathbf{6 . 0 3 b}$ \\
$\begin{array}{c}\text { hour } \\
\text { mean }\end{array}$ & $\mathbf{2 2 . 6 0 a}$ & $\mathbf{1 3 . 7 6 b}$ & $\mathbf{1 2 . 5 5 b}$ & $\mathbf{9 . 5 6 b}$ & $\mathbf{2 . 6 4 c}$ & $\mathbf{1 . 0 6 c}$ & $\mathbf{. 8 1 c}$ & \\
\hline
\end{tabular}

means with different letters are significantly different. For week $L S D=3.47$, for hour $=4.59$ and for interaction $=9.16$ respectivelly, $\mathrm{df}=224 \mathrm{p}=0.05$ 
Reyes-Carrillo et al.: Polen collection and bee forager in cataloupe

During the first week the weight of collected pollen was low, but it was clearly higher early in the morning until 12:30 hr when it dropped. Low collection was observed through the afternoon until 14:30 hr. During the second week, collection increased compared with the previous one (Table 1). In the third week, at 8:30 hr, higher corbicular pollen weight was obtained but it dropped from this hour gradually to a minimum at 14:30. Throughout our study, pollen collection was highest in the morning, and generally falling to low levels shortly after $11: 30 \mathrm{hr}$.

A large reduction in pollen collected was observed in the $4^{\text {th }}$ week (Table 1). After the $8: 30 \mathrm{hr}$ collection suddenly dropped and remained low. This was unexpected, because in this period the cantaloupe vines are long enough to maintain a plentiful bloom and therefore a higher pollen amount. Significant differences were observed in the pollen amount collected at different weeks and hours as can be seen in Table 1.

The highest pollen quantity was harvested at $8: 30 \mathrm{hr}$, intermediate amount between 9:30 hr and 11:30 hr and lesser amount from 12:30 hr to the last sample hour ( $p=0.05$; Table 1). Between 11:30 hr and 14:30 hr we observed the transportation of water drops coming from the brood chamber into the pollen trap trays. This pollen and water foraging behavior might be temperature and humidity based (Fig. 1). This could be explained, since, during the third week, early in the morning $(8: 30 \mathrm{hr})$ temperature was about $26^{\circ} \mathrm{C}$, increasing quickly during the rest of the morning until reaching a maximum at about $13: 30 \mathrm{hr}\left(39.5^{\circ} \mathrm{C}\right)$.

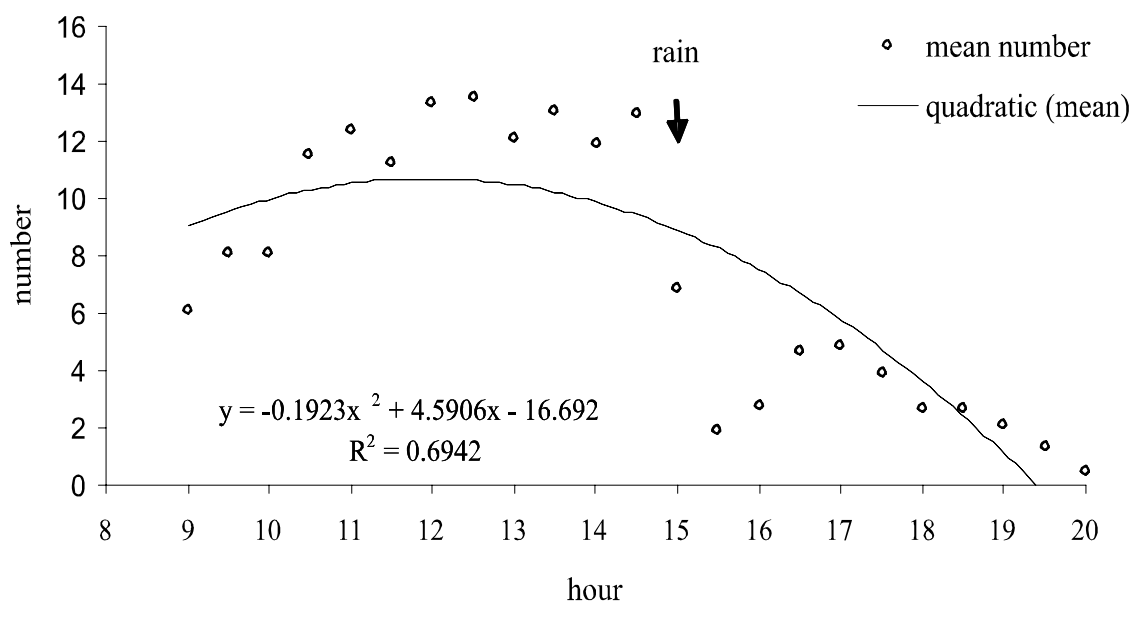

Figure 1

Relative humidity and air temperature at different hours in the cantaloupe crop.

Bee distribution in the field crop: Honey bees began their foraging flights after 8:00 am and growing their number as the morning progressed (Fig. 2). They reached the statistically significant highest number from about 10 :30 hours $(11.5 \pm 1.70 n=16$ bees per $10 \mathrm{~m}$ transect) and foragers showed a sustainable presence until 14:30 hr $(12.9 \pm 1.93$ $\mathrm{n}=16$ bees). From this hour, bees began to diminish but a sudden rain shower at $15: 30 \mathrm{hr}$ 
(Fig. 1) stopped the bee flights. After that rainy period they continued to decrease until evening. Foraging activity ceased totally at $20: 30 \mathrm{hr}$; that is, before sunset occurred at 19:59 hr to $20: 01 \mathrm{hr}$ during this time.

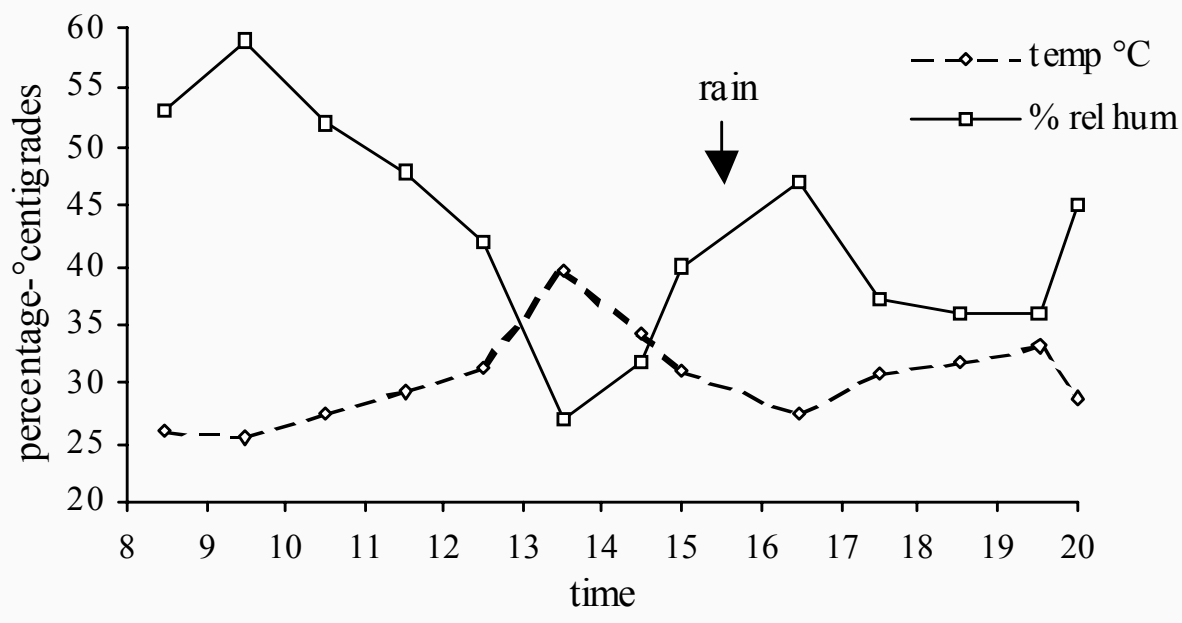

Figure 2

Mean number of honey-bees in the cantaloupe crop at different hours during the third week of bloom.

No statistical significant differences were found in the number of foraging bees at different distances from the apiary $(p<0.05)$, thus the foraging bees were uniformly distributed in the field crop (Table 2).

Table 2

Mean number of bees in the cantaloupe crop at different distances from the apiary.

\begin{tabular}{ccccc}
\hline distance & $\mathbf{2 5 ~} \mathbf{m}$ & $\mathbf{5 0 ~ m}$ & $\mathbf{7 5 ~ m}$ & $100 \mathrm{~m}$ \\
\hline mean bee number & $\mathbf{7 . 2 5 \pm 0 . 3 2}$ N.S. & $\mathbf{7 . 4 1 \pm 0 . 2 8 ~ N . S . ~}$ & $\mathbf{7 . 9 3 \pm 0 . 2 5 ~ N . S . ~}$ & $\mathbf{6 . 7 8 \pm 0 . 2 6 ~ N . S . ~}$ \\
\hline
\end{tabular}

N.S. Non statistically significant difference $L S D=1.19 \mathrm{df}=276 \mathrm{p}=0.05$

\section{DISCUSSION}

Pollen is the main attractant for most pollinators, an important part of the diet of the plant visitors, and an essential component on sexual reproduction and gene flow of plants (Kearns \& Inouye 1993). Seed plants that are animal pollinated generally have pollen that it is large, sculptured, and coated with an adhesive wax or oily substance; consequently that causes pollen grains to clump to each other and to pollinating animals, deters herbivores, attracts pollinators, and is a food source primarily for pollinators (Gorelick 2001). 
Reyes-Carrillo et al.: Polen collection and bee forager in cataloupe

Honey bees, adjust their pollen foraging activity according to the need for pollen within the colony, determined by the amount of stored pollen and young brood present in the hive (Dreller \& Tarpy 2000). Pollen-foraging behavior is correlated with the responsiveness to sucrose (Amdam et al. 2004). ). In our trial, in the warmest day hours, the nectar gatherbees is well known (vonFrisch 1976; Kuhnholz \& Seeley 1997) as it is their effective communication among themselves to adjust foraging behavior (Seeley 2002; Pankiw 2004; Wright \& Smith 2004).

Returning nectar foragers can rapidly modify their behavior by the influence of their nestmates. Thus, the social context is important for the futures behavior of the foragers, introducing temporal changes in their motivational levels during their expend at the hive (Farina 2000). In this trial, relative humidity $(\mathrm{RH})$ dropped as the dawn passed, but a sudden five-minutes rain shower at 15:30 hr affected the foraging behavior of bees that abandoned the field crop. In La Laguna, high temperatures and low relative humidities are common environmental conditions at this time of the year (Schmidt 1989).

In this study the $R^{2}$ value (0.69) had an acceptable confidence for predicting the number of bees at a certain hour but maybe this value was not high enough due to the bee population loss in the cantaloupe field because of the shower. In this trial we can observe that honeybees were present in the cantaloupe flower-vines all day long. Some crops, including blueberries and cherries are $90 \%$ dependent on honey bee pollination. Several crops, like almonds, depend entirely on honey bee for pollination. Honey bees, therefore, are an integral part of the modern agricultural success story (de Vries 2000).

The results of the trials showed that the foraging-bees were collecting higher pollen amounts early in the morning and a small pollen quantity from noon to the end of the day, and forager-bees were in the field all day long in a well defined pattern. This is important information to schedule pesticide sprays in the field crop, since it is well known that the pollinator scarcity has often been caused by agrichemicals which have even damaged commercial honey bee colonies (DeLaplane \& Mayer 2004). The peak period of honey-bee activity in the cantaloupe crop was usually mid morning (McGregor 1976) and bees learned quickly when they can get the best reward while they are foraging (Hempel de lbarra et al. 2000). According with our results, chemical applications for pest control could be done during the afternoon or, if possible, at night to minimize damages to bee colonies.

A honey bee can fly a considerable distance to collect nectar or pollen (Eckert 1933; vonFrisch 1976), but once there, it will tend to be confined in a small area mainly if the selected species are a good food source (Levin 1959). In our case we had a uniform distribution of bees at the different distances from the hive that were evaluated (from 25 to $100 \mathrm{~m}$ ).

We conclude that honey bees collected the main quantity of pollen during the second and third weeks of bloom and during the first hours in the morning, but they can continue foraging in a small amount from noon to late afternoon. Foraging bees started visiting the cantaloupe crop at about 8:00 hr in the morning and reached a peak between 10:30 hr and 14:00 hr, when their presence in the crop declined to cease totally before sunset. 


\section{ACKNOWLEDGEMENT}

We thank Fundación Produce Coahuila, A.C. and Cámara Agrícola y Ganadera de Torreón for the financial support and Agronomy students from the Universidad Autónoma Agraria Antonio Narro, Unidad Laguna, Fernando Castrejón, Pedro Murillo, José Alfredo Jiménez and Aldo Cornejo for their technical assistance.

\section{LITERATURE CITED}

Amdam, G. V., K. Norberg, M. K. Fondrk \& R. E. Page. 2004. Reproductive ground plan may mediate colony-level selection effects on individual foraging behavior in honey bees. Proc. Nat. Acad. Sci. USA 101: 11350-11355.

Briscoe, A. \& D. Chittka. 2001. The evolution of color vision in insects. Annu. Rev. Entomol. 46: 471-510.

de Vries, G. E. 2000. Essential task for honeybees Trends. Plant. Sci. 5: 277.

DeLaplane, K. S. \& D. F. Mayer. 2004. Crop pollination by bees. University Press Cambridge, U.K.

Dreller, C. \& D. R. Tarpy. 2000. Perception of the pollen need by foragers in a honey bee colony. Anim. Behav. 59: 91-96.

Eckert, J. E. 1933. The flight range of the honeybee. J. Agric. Res. 47: 257-285.

Eischen, F., B. A. Underwood \& A. Collins. 1994. The effect of delaying pollination on cantaloupe production. J. Apic. Res. 33: 180-184.

Endress, P. K. 2001. Evolution of floral symmetry. Curr. Opin. Plant. Biol. 4: 86-91.

Farina, W. M. 2000. The interplay between dancing and trophallactic behavior in the honey bee Apis mellifera. J. Comp. Physiol. 186: 239-245.

Gorelick, R. 2001. Did insect pollination cause increased seed plant diversity? Biol. J. Linn. Soc. 74: 407-427.

Hagler, J. R. \& C. G. Jackson. 2001. Methods for marking insects: Current techniques and future prospects. Annu. Rev. Entomol. 46: 511-543.

Hempel de Ibarra, N., M. Vorovyev, R. Brandt \& M. Giurfa. 2000. Detection of bright and dim colours by honeybees. J. Exp. Biol. 203: 3289-3298.

Kearns, C. A. \& D. W. Inouye. 1993. Techniques for pollination biologists. University Press of Colorado, Niwot ,Colorado, USA.

Kearns, C. A., D. W. Inouye \& N. Waser. 1998. Endangered mutualism: The conservation of plant- pollinator interactions. Ann. Rev. Ecol. Syst. 29: 83-106.

Kuhnholz, S. \& T. D. Seeley. 1997. The control of water collection by bees. Behav. Ecol. Sociobiol. 41: 407-422.

Lee, W. R. 1961. The nonrandom distribution of foraging bees between apiaries. J. Econ. Entomol. 52: 928-933.

Levin, M. D. 1959. Distribution patterns of young and experienced honey bees foraging on alfalfa. J. Econ. Entomol. 52: 969-971.

McGregor, S. E. 1976. Insect pollination of cultivated crop plants. Agriculture Handbook No. 496. United States Department of Agriculture: Washington, D.C., U.S.A.

Pankiw, T. 2004. Brood pheromone regulates foraging activity of honey bees (Hymenoptera: Apidae). J. Econ. Entomol. 97: 748-51.

Ricketts, T. H., G. C. Daily, P. R. Ehrlich \& C. D. Michener. 2004. «Economic value of tropical forest to coffee production.» Proc Nat Acad Sci USA 101: 12759-12582. 
Reyes-Carrillo et al.: Polen collection and bee forager in cataloupe

Rush, S., J. Conner \& P. Jennetten. 1995. The effects of natural variation in pollinator visitation on rates of pollen removal in wild radish, Raphanus raphanistrum (Brassicaceae). Am. J. Bot. 82: 1522-1526.

Russell, D., R. Meyer \& J. Bukowski. 1998. Potential impact of microencapsulated pesticides on New Jersey apiaries. Am. Bee J. 138: 207-210.

Schmidt, R. H. 1989. The arid zones of Mexico: climatic extremes and conceptualization of the Sonoran Desert. J. Arid. Environ. 16: 241-256.

Seeley, T. D. 2002. When is self-organization used in biological systems? Biol. Bull. 202: 314-318.

Sheffield, C. S., R. F. Smith \& P. G. Kevan. 2005. Perfect syncarpy in apple (Malus x domestica 'Summerland Mclntosh') and its implications for pollination, seed distribution and fruit production (Rosaceae: Maloideae). Ann. Bot. 95: 583-591.

Steel, R. G. D. \& J. H. Torrie. 1960. Principles and procedures of statistics. McGraw-Hill Book Company, Inc. New York, U.S.A.

Varassini, I. G., J. R. Trigo \& M. Sazima. 2001. The role of nectar production, flower pigments and odour in the pollination of four species of Passiflora (Passifloraceae) in south-eastern Brazil. Bot. J. Linn. Soc. 136: 139-152.

vonFrisch, K. 1976. Bees their vision, chemical senses, and language. Rev. ed. Second printing. Cornell University Press, Ithaca, New York, U.S.A.

Waller, G. D. 1980. A modification of the O.A.C. pollen trap. Am. Bee. J. 120: 119-121.

Waser, N. M., L. Chittka, M. V. Price, N. M. Williams \& J. Ollerton. 1996. Generalization in pollination systems, and why it matters. Ecology 77: 1043-1069.

Wright, G. A. \& B. H. Smith. 2004. Variation in complex olfactory stimuli and its influence on odour recognition. Proc. R. Soc. Lond. B 271: 147-152.

Recibido: 2 de septiembre 2005

Aceptado: 8 de noviembre 2006 